\title{
Dispersal mechanisms in Lavandula stoechas subsp. pedunculata: autochory and endozoochory by sheep
}

\author{
Ana M. Sánchez and Begoña Peco* \\ - Departamento de Ecología, Universidad Autónoma de Madrid, Campus Cantoblanco, Madrid 28049, Spain
}

\begin{abstract}
It is normally assumed that Lavandula stoechas subsp. pedunculata (Miller) Samp. ex Rozeira (Labiatae) is dispersed by autochory in spite of the clear pioneer nature of the species. This paper examines the efficiency of autochorous dispersal (seed rain) and the possibility that the species is also dispersed endozoochorally by sheep. Seed rain was measured using pitfall traps and adhesive strips in summer 1999. The viable seed content in sheep dung was measured by greenhouse germination of dung collected monthly in the summers of 1998 and 1999. Two experimental tests were also conducted to ascertain whether dung-borne seeds could be established under field conditions and to evaluate the effect of added dung in the establishment of seeds taken from plants. The recorded seed rain was 2544 seeds $\mathrm{m}^{-2}$ inside the Lavandula patches, with an aggregated distribution. Autochory around the mother plant fitted a negative exponential distribution, with $90.5 \%$ concentrated in a $0-30 \mathrm{~cm}$ radius and a maximum distance of $1 \mathrm{~m}$. Viable Lavandula seeds were found in $73 \%$ of the examined dung samples, with an average of 5.5 seeds per sample $(6 \mathrm{~g})$ and a high interand intra-annual variation. This high seed content, together with the daily sheep movements over several kilometres, make the species highly dispersible, possibly explaining its clear pioneer nature. Moreover, available data suggest that seeds in sheep dung can germinate and establish under natural conditions, and that dung addition has a positive effect on species - establishment.
\end{abstract}

Keywords: autochory, endozoochory, Lavandula stoechas subsp. pedunculata, Mediterranean shrubland, sheep, Spain

${ }^{*}$ Correspondence

Fax: +34-91-3978001

Email: begonna.peco@uam.es

\section{Introduction}

Propagule dispersal, whether by sexual reproduction or vegetative growth, is the only mechanism that allows plants to colonize new habitats. It is therefore not strange that during evolution, many strategies have arisen in the plant kingdom to optimize diaspore dispersal, using different agents (Ridley, 1930; Van der Pijl, 1982). Incapacity for dispersal, whether due to a lack of an efficient dispersal mechanism, habitat fragmentation or the removal of dispersal agents, may restrict species distribution (Primack and Miao, 1992; Tilman, 1997). However, dispersal alone is not enough to produce colonization, as seeds are not always able to germinate and establish at the point where they have been deposited (Booth and Larson, 1988; Eriksson and Ehrlén, 1992; Schupp, 1995; Nathan and Muller-Landau, 2000).

Several herbivores have been found to be endozoochorous dispersal agents for diaspores (Janzen, 1984; Gardener et al., 1993a, b; Malo and Suárez, 1995a; Pakeman et al., 1999; Malo et al., 2000). In ecosystems with a long history of human involvement, such as the semi-natural grasslands in the Mediterranean Basin and continental Europe, livestock play a particularly important role in dispersal processes (Welch, 1985; Russi et 1., 1992; Malo and Suárez, 1995b). The abandonment of traditional grazing patterns in these areas is having serious repercussions in the dispersal potential of many species, leading to impoverished communities (Malo and Suárez, 1996; Poschlod and Bonn, 1998; Poschlod et al., 1998). On the other hand, in areas where livestock grazing is relatively recent, domestic herbivores have the opposite effect, facilitating the colonization of new areas by species which, until the arrival of livestock, had a low dispersal capacity (Brown and Archer, 1987, 1989; O'Connor and Roux, 1995).

The role of liyestock as endozoochorous dispersers of Mediterranean shrub species has generally been underestimated. On the Iberian Peninsula, these species have been classified on the basis of palaeobotanic, chorological and form-function data into two clearly distinguished genus groups: seeders 
and resprouters (Herrera C.M., 1984b, 1992; Herrera J., 1987). The former group contains species unable to resprout, which generally produce dry fruit with a large number of small seeds. The second group consists of resprouting species with medium- or large-sized seeds and a higher rate of biotic dispersal, primarily bird-borne endozoochory (Herrera C.M., 1984a, 1995; Jordano, 1995). The latter group includes genera from a pre-Mediterranean flora, while the former genera are less numerous but much more diversified and distributed solely in the Mediterranean Basin. They form a floristic element that has developed since the Pliocene and have thus evolved under the characteristic selective Mediterranean pressure (Herrera C.M., 1984b, 1992).

'Seeder' shrub species are mainly linked to early successional communities and heavily disturbed environments. In these environments, the aerial part of the plant grows quickly and tends rapidly to produce many small seeds, which ought to provide the species with a high colonizing capacity. However, the majority of these species lack structures associated with specific dispersal mechanisms. Their dry fruits are unattractive to birds (Herrera C.M., 1984b, 1992; Keeley, 1991), while myrmechory, quite common in other Mediterranean regions (Rice and Westoby, 1981; Milewski and Bond, 1982; Bond et al., 1991), is not a common mechanism in Mediterranean Basin shrublands (Guitián and Sánchez, 1992; Wolff and Debussche, 1999). Finally, while some genera do have structures that favour anemochory or exozoochory, they are generally a minority (Guitián and Sánchez, 1992). In the case of labiates, the lack of dispersalrelated structures has been one reason for the assumption that these species use abiotic dispersal, predominantly autochory. However, the seed rain caused by this type of dispersal, instead of providing a strong dispersal capacity, is characterized by the concentration of a large proportion of the seeds immediately around the mother plant, with very short maximum scatter distances (Friedman and Orshan, 1975; Keeley, 1991; Willson, 1992).

In this context, the present paper analyses the dispersal mechanisms of Lavandula stoechas subsp. pedunculata (Miller) Samp. ex Rozeira (Labiatae) (henceforth Lavandula), a common Mediterranean shrub in the centre of the Iberian Peninsula, which is a member of the seeder group of species. It is associated with heavily degraded soils and is normally linked to abandoned crop and grasslands (Costa, 1974; RivasMartínez, 1990). There is a large body of literature on the biology and ecology of the flower and fruit of other subspecies in the same genus (Devesa et al., 1985; Herrera J., 1987, 1991, 1993, 1997a; Muñoz and Devesa, 1987), and the positive effect of mild disturbance on its reproduction potential has been described (Herrera J., 1997b). However, to date there have been no specific studies of its dispersal mechanisms, apart from one paper that analyses the endozoochoric dispersal of Lavandula stoechas by Testugo grineca (Cobo and Andreu, 1988). The species did not seem to be a regular part of the diet of this tortoise, and in feeding experiments the seeds could not be checked for viability after passage through its gut due to the small number found. We know that its fruits consist of four nutlets which are dispersed separately. These dispersal units [henceforth seeds using the Bekker et al. criterion (1998)] are almost elliptical, with a mean weight of $0.00091 \mathrm{~g}$ and mean length of $1.79 \mathrm{~mm}$ along the longest axis (unpublished data). They lack dispersal structures and remain. enclosed in the calyx until the calyx opens in summer, allowing their dispersal (Muñoz and Devesa, 1987).

We may, therefore, assume that the seeds are dispersed by autochory, although the clear pioneer nature of Lavandula suggests the existence of a more efficient dispersal mechanism. Our initial hypothesis pointed to sheep, the role of which as endozoochorous dispersers has been analysed elsewhere (Gibson et al., 1987; Russi et al., 1992). In the study area, Lavandula infructescence consumption has often been observed, and if the seeds are not destroyed by the chewing mechanism or damaged during passage through the intestine, they may well be dispersed by sheep. In addition, the pattern of daily sheep movement means that this type of dispersal can be effective over several kilometres. Finally, the microenvironment created by the sheep dung could favour seed establishment in environments with limited nutrients, such as this oligotrophic shrubland.

Our aims were therefore to: (1) define the number and distance of seeds dispersed by autochory; (2) quantify the number of viable seeds in sheep dung and their inter- and intra-annual variation; (3) analyse whether the seeds excreted by sheep can be established under field conditions; and (4) analyse the effect of sheep dung addition on the establishment of Lavandula seedlings germinated from seeds taken directly from the plant.

\section{Materials and methods}

\section{Study area}

The study was conducted in Pedrezuela, a municipality $50 \mathrm{~km}$ north of Madrid on the southern side of the Sierra de Guadarrama (central Iberian Peninsula). The study area altitude ranges between 700 and $900 \mathrm{~m}$ and has a continental Mediterranean climate $\left(13.2^{\circ} \mathrm{C}\right.$ mean annual temperature; $540 \mathrm{~mm}$ annual rainfall). The rock substrate is gneiss, with an A horizon of shallow, loose soils. The potential 
vegetation is forests composed of holm oak (Quercus ilex subsp. ballota) and juniper (Juniperus oxycedrus). The present vegetation composition is the result of many centuries of land use, including tree felling, itinerant ploughing, grazing, etc. (Montoya et al., 1988), and its relatively recent abandonment except for the existence of low-intensity, extensive sheep grazing in some sectors. It now consists of shrub formations with scattered stands of holm oak and - juniper. Lavandula stoechas subsp. pedunculata is the predominant shrub species, found in virtually monospecific patches, with a mean density of 3.9 individuals $\mathrm{m}^{-2}(\mathrm{SD}=1.9)$ and mean height of $45.7 \mathrm{~cm} \quad(\mathrm{SD}=12.80)$. Individuals of other shrub species such as broom (Cytisus scoparius), thyme (Thymus mastichina) and a type of low cistus (Halimium umbellatum subsp. viscosum) also appear sporadically.

\section{Autochorous dispersal}

The autochorous dispersal process was studied in summer 1999 between July, when the Lavandula seeds mature, and October, when seed germination begins. Measurements were conducted in ungrazed areas to prevent fruit consumption by, livestock. We used two standard methods to measure seed rain: buried pitfall traps and adhesive strips (Werner, 1974; Rabinowitz and Rapp, 1979; Booth and Larson, 1988). The plastic pitfall traps had a diameter of $2.2 \mathrm{~cm}$ and a depth of $5 \mathrm{~cm}$. The bottom was perforated to release rainwater and then buried, leaving the lip at ground level. Both the smooth wall surface and the narrow-necked opening made it impossible for insects entering the traps to escape with seeds. The adhesive traps consisted of $5 \times 100 \mathrm{~cm}$ plastic strips impregnated with a non-drying adhesive substance (Temoocid, Kollant S.p.A., Padova, Italy).

To evaluate the seed rain inside the Lavandula patches, we defined a 300-m transect along which we left 30 pitfall traps at random. In addition, to measure

- the seed rain in the ecotone zones between shrub and grassland, we chose 12 Lavandula individuals at random at least $50 \mathrm{~m}$ apart, which were in the transition zone between these communities. We laid seven traps at a distance of $0,10,30,60,100,300$ and $500 \mathrm{~cm}$ from the centre of each individual. The traps $(n=30+84)$ were replaced every 16 days from 1 July to 7 October 1999. We thus gathered six sets of seed rain data covering $16-\mathrm{d}$ periods.

Adhesive traps were also extended outwards from the base of the other 12 isolated and randomly chosen adult plants $(n=12)$. The strips were left four times during summer at approximately $20-\mathrm{d}$ intervals, and exposed to the seed rain for $48 \mathrm{~h}$. On each occasion, we noted the number of seeds attached to each strip and the distance from the adult individual. In other -studies, adhesive traps have been exposed to the seed rain for longer periods of 3 weeks or a month (Booth and Laršon, 1988). However, in our case, this was not considered advisable due to the large number of insects, bark, soil, etc. that also adhered to the strips and reduced their effectiveness.

\section{Endozoochorous dispersal}

The sheep dung samples were gathered in the grazed sector of the study area in July, August and September 1998 and 1999, coinciding with the period when the mature Lavandula seeds were available for consumption. On each occasion, we collected 20 samples of fresh sheep dung composed of 20 clumped pellets, thus permitting the assumption that each sample was from a different individual. After collection, the samples were air dried and stored until the following October. They were then partially crushed, taking three $2 \mathrm{~g}$ subsamples, which were each mixed with $2 \mathrm{~g}$ of sterile soil for greenhouse growth. The mixture was maintained for 21 months, recording and removing every Lavandula seedling that emerged. We also noted and removed all germinating seedlings of other species. The samples were kept moist throughout the experimental period except for the 3 summer months ( 9 months after the start of the experiment) to mimic field conditions.

\section{Seedling establishment}

After finding evidence of viable Lavandula seeds in sheep dung, we designed a test (Test 1) to check whether these seeds were capable of germination and establishment in the field. This experiment was conducted on the grounds of the Autónoma University of Madrid, $20 \mathrm{~km}$ south of the study area. The soil conditions were similar to those of the study area, with the difference that Laviandula was absent from both the vegetation and the seed bank. Vegetation, primarily annual species, was cut in a 50 $\times 50 \mathrm{~m}$ area in order to facilitate sowing and location of each plot. A total of 20 plots measuring $20 \times 20 \mathrm{~cm}$ were selected at random, separated by a minimum distance of $2 \mathrm{~m}$ and marked by two nails buried for subsequent location using a metal detector. Six grams of sheep dung, taken from the remainder of 20 of the 60 samples collected in summer 1998, were sown in each plot.

We also studied the potential effect of the microenvironment created by the dung on plant establishment (Test 2). This test was conducted on the same site as the previously described area, using the same procedure. In this case, we set 40 quadrats measuring $20 \times 20 \mathrm{~cm}$ and randomly designated one of two treatments to each one: (1) sowing with 20 Lavandula seeds; (2) sowing 20 Lavandula seeds mixed 
with $6 \mathrm{~g}$ of sheep dung initially without Lavandula seeds. The seeds used in this test were collected from 20 individual plants chosen at random in the study area in summer 1998. The seeds from all individuals were homogenized together prior to sowing, and selected using a pressure test to eliminate parasitized or empty seeds.

In both cases, the seeds were sown in April 1999, the area was watered twice weekly for two months and then monitored to count the emerged seedlings. Seedlings were counted again in September.

\section{Statistical analysis}

In order to analyse the seed rain distribution inside the Lavandula patches, we calculated the variance/mean quotient and tested its deviation from value 1 in a random distribution (Kersaw, 1975). In the case of seed distribution in relation to distance from the edge of the patch, we checked the goodness of fit $\left(R^{2}\right)$ of the curves of seed rain to a negative exponential distribution. For inter- and intra-annual variation in the number of germinating seedlings found in the sheep dung, samples were analysed using a two-factor ANOVA (month and year) applied to the previously log-transformed variable. The microclimate effect of the dung on Lavandula establishment was analysed using the Kruskall-Wallis test $(\mathrm{K}-\mathrm{W})$, given that the number of seedlings did not meet the requirement for normality. The SYSTAT programme (Wilkinson, 1986) was used for the statistical analyses.

\section{Results}

\section{Autochory}

A total of 29 Lavandula seeds were collected inside the patch (pitfall traps) over the summer period, of which 10 entered the traps inside the infructescence. An average of 0.97 seeds $(S D=2.01)$ was found at each sampling point, suggesting a total of 2544 seeds $\mathrm{m}^{-2}$ for the total period (July-October) when the traps were in the field, or 26 seeds $\mathrm{m}^{-2} \mathrm{~d}^{-1}$. The variance/mean ratio was 4.12 , indicating a contagious spatial distribution $(t=12.0, P<0.001, n=30)$.

The seed rain recorded at the edge of the patches was minimal. In most cases, no seeds were found in either the pitfall or adhesive traps. Total seeds collected in the study period were 72 and 47, respectively.

The seed rain in relation to the distance from the edge of the Lavandula patch recorded by the two methods described a negative exponential curve (Fig. 1 ), i.e. the majority of seeds were concentrated around the mother plant: $95 \%$ and $85 \%$ of seeds were less than $30 \mathrm{~cm}$ away in the pitfall and adhesive traps, respectively. The highest seed density was found in the first $10 \mathrm{~cm}$ from the mother plant, with a daily seed rain of 15.6 and 16.4 seeds $\mathrm{m}^{-2}$, respectively. Maximum distances found were $100 \mathrm{~cm}$ in the case of the pitfall traps and $97 \mathrm{~cm}$ in the case of the adhesive traps. The percentage of seeds collected from inside the infructescences, rather than as free seeds, was very high in both cases (roughly $70 \%$ in both cases). No clear time pattern was found for the seed rain (Fig. 2).

\section{Endozoochory}

The majority of germinating seedlings $(90 \%)$ appeared in dung during the first 3 months of greenhouse cultivation. Viable seed density per sample (6 $\mathrm{g}$ of dung) was lower in the 1998 samples than the 1999 collection, as was the case with the percentage of samples with a presence of seeds (Table 1).

The ANOVA revealed significant inter-annual and inter-month differences in the number of dung-borne viable seeds. The trend in the number of seeds differed within each year, and thus the interaction between the two factors was significant (Table 1, Fig. 3 ). Both the number of species and the total number of germinating seedlings of herbaceous species were higher in 1998 than in 1999 (Table 2). However, in the 1999 samples there was an increase in the number of woody species represented, including viable seeds of Rubus sp., Santolina rosmarinifolia, Cytisus scoparius and Halimium umbellatum subsp. viscosum.

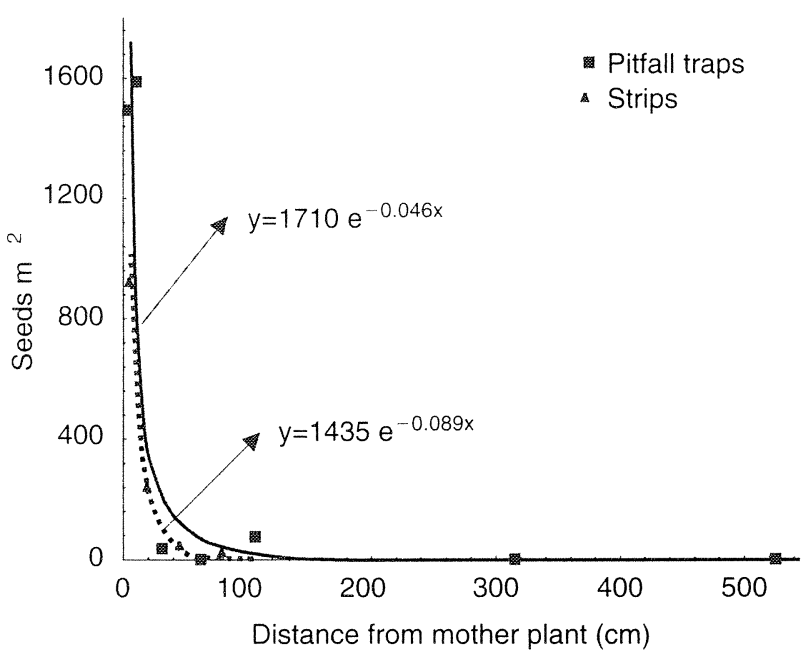

Figure 1. Results of seed rain distribution with respect to the mother plant, analysed using two sampling methods. Values show mean seed densities recorded during the complete study period. The fit to the respective negative exponentials: for pitfall traps, $R^{2}=0.90$; for adhesive strips, $R^{2}=0.99$. 

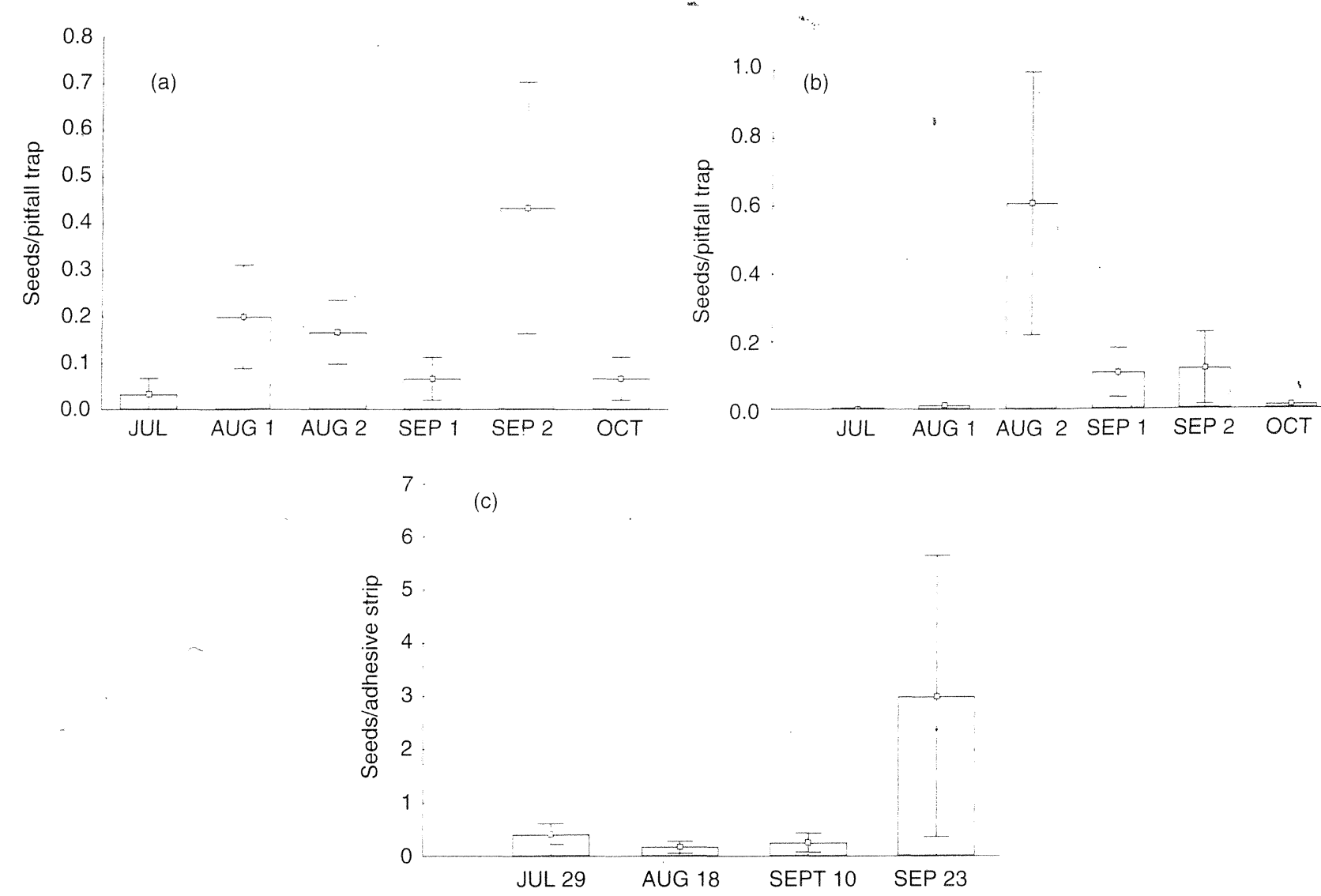

Figure 2. Seed rain distribution (mean \pm SE) during the study period: (a) inside the Lavindula patches; (b) on the edge of the Lavandula patches, measured with pitfall traps; (c) on the edge of the Lavandula patches, measured with adhesive traps.

Table 1. Results of two-factor ANOVA (year and month) on the number of viable Lavandula seeds found in sheep dung samples during greenhouse cultivation

\begin{tabular}{lrrrc}
\hline & MS & df & $F$ & $P$ \\
\hline Year & 42.12 & 1 & 58.26 & $<0.001$ \\
Month & 4.96 & 2 & 6.86 & 0.002 \\
Year $\times$ Month & 2.89 & 2 & 3.99 & 0.02 \\
\hline
\end{tabular}

\section{Establishment}

In the 20 dung samples used to analyse establishment under field conditions, we only recorded two plants with an average of 0.1 established seedlings per $6 \mathrm{~g}$ of sown dung. Given that the mean number of viable seeds obtained from greenhouse germinating seedlings of the same samples was 1.8 viable seeds per $6 \mathrm{~g}$ of dung, establishment under field conditions represented $5.46 \%$ of the viable seeds.

The number of pre-summer seedlings established from seeds taken from the plant was significantly higher in the samples with dung addition than in the control samples (K-W: $H=4.8, P$ $=0.03$ ) (Table 3), where the percentage of establishment was 13.5 and $3 \%$ of all sown seeds respectively. No seedlings survived beyond the summer in any of the tests.

\section{Discussion}

\section{Autochory}

The number of seeds dispersed during summer inside the Lavandula shrubland was quite high (2544 seeds $\mathrm{m}^{-2}$ ). However, distances from the edge of the Lavandula populations reached by seeds were less than $1 \mathrm{~m}$ in most cases. Together with the total lack of seeds in the 3- and 5-m traps, this clearly suggests a short range of autochory as a dispersal mechanism.

The Lavandula patch interior had a higher seed density than the surrounding areas, but was generally not appropriate for seedling establishment. The Lavandula thickets in the study area were on shallow, 


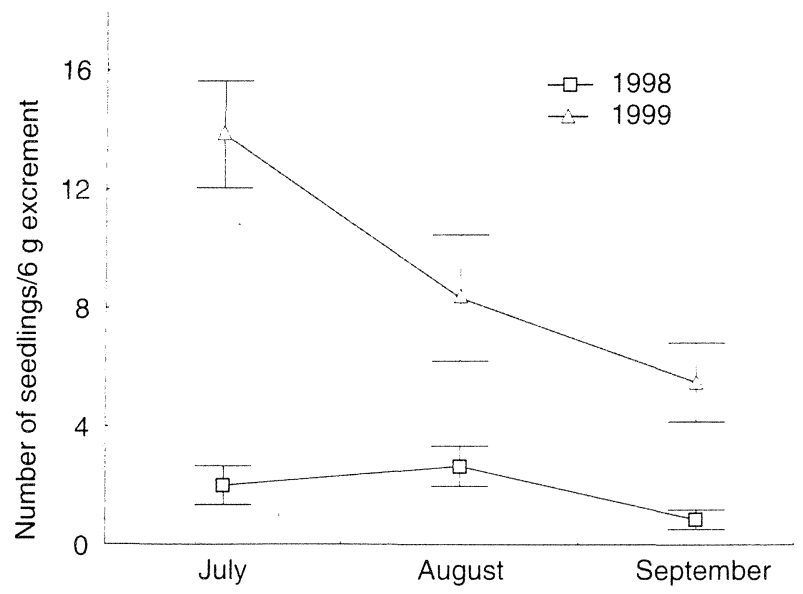

Figure 3. Number of viable Lavandula stoechas subsp. pedunculata seeds (mean \pm SE) found in the sheep dung samples in each study month and year.

very sandy and hence unproductive soils. In addition, Lavandula populations are dense formations, with rarely more than $1 \mathrm{~m}$ between individual plants (Díaz-Barradas et al., 1999). Moreover, similar allelopathic effects to those described for other labiate thickets cannot be dismissed (Vokou and Margaris, 1986; Vokou, 1992; Murray, 1998). Therefore, it seems logical to assume that this environment has a high level of competition in which density-dependent processes may have a negative effect on Lavandula seeds and seedlings (Howe and Smallwood, 1982). In fact, during our study the seedling mortality rate during the first year of life inside the Lavandula patches was almost 100\% (Sánchez and Peco, 1999).

In arid ecosystems, species often lack specialized dispersal mechanisms, with most seeds clustered around the adults (Friedman and Orshan, 1975; Shmida and Ellner, 1983). Under the characteristically extreme conditions of these environments, shade under adult plants is the most likely factor governing seedling survival. Generally, the high seedling concentration around adult individuals would suggest that they have the highest likelihood of establishment, although this does not seem to be the case for Lavandula, as no differences in mortality have been found under adult plants in comparison to clearings between the Lavandula thickets (Sánchez and Peco, 1999), nor have juveniles been found around adults. Therefore, it seems unlikely that the shade provided by the mother plant provides sufficiently favourable microenvironmental conditions to ensure a higher probability of survival.

Seed densities recorded in the traps inside the Lavandula patches from July to October were $5.75 \%$ of estimated seed production in the study area $[11,355$ seeds per individual $(\mathrm{SD}=2656.59), \quad 3.9$ individuals $\mathrm{m}^{-2}(\mathrm{SD}=1.9), 44,283$ seeds $\mathrm{m}^{-2}$, unpublished data]. This may be an underestimate of seed rain, given the small capture area and the aggregated seed distribution. In addition, the production estimate is based on the number of infructescences counted at the start of summer, some of which may have been eaten during the course of the period. Granivore Messor ants were seen to be engaged in intense collection of Laviandula seeds in the same area (Azcárate et al., 1998), harvesting partial or complete infructescences from the plant (personal observation). Whatever the case, the data suggest that a number of seeds were not dispersed during the study period, as confirmed by the large number of seeds found in infructescences collected in winter. Thus, while most germination takes place in autumn (Sánchez and Peco, 1999), the possibility that some of these seeds are dispersed at a later date and germinate or enter the soil seed bank should not be ignored. These seeds can form persistent seed banks (Traba, 2000), because viable seeds of the species can be detected at a depth of more than $5 \mathrm{~cm}$ in soil (Thompson et al., 1987).

While the seed rain time distribution appears to reach a peak in August-September, the lack of consistent time patterns throughout the sampling periods may be related to the occasional presence in the traps of infructescences with a large number of seeds.

\section{Endozoochorous dispersal}

The results show that Lavandula seeds are capable of germinating after travelling through the sheep gut.

Table 2. Viable seed contents found in 6-g samples of sheep dung. Listed for Lavandula: percentage of samples containing viable seeds, total number of germinating seedlings and mean ( \pm SD) density of viable Lavandula seeds per dung sample. Listed for herbaceous species: number of species, total number of germinating seedlings and mean $( \pm \mathrm{SD})$ density of viable seeds per dung sample

\begin{tabular}{cccccccc}
\hline & \multicolumn{3}{c}{ Lavandula } & & \multicolumn{3}{c}{ Herbaceous species } \\
\cline { 2 - 3 } \cline { 7 - 8 } & $\%$ & Total & Mean density & & Number of species & Total & Mean density \\
\hline 1998 & 55 & 110 & $1.83( \pm 2.65)$ & & 67 & 2722 & $45.37( \pm 34.16)$ \\
1999 & 90 & 544 & $9.23( \pm 8.59)$ & & 40 & 318 & $5.3( \pm 5.56)$ \\
\hline
\end{tabular}


Table 3. Effect of dung addition on the germination of Lavandula seeds collected from plants and sown with and without sheep dung. Total, median, maximum and minimum number of established seedlings are shown for the treatments

\begin{tabular}{lcccc}
\hline Treatment & Total & Median & Max. & Min. \\
\hline With dung & 54 & 0.5 & 4 & 0 \\
Without dung & 12 & 0 & 12 & 0 \\
\hline
\end{tabular}

The number of viable Lavandula seeds found per sample and the number of samples containing seeds are both considered to be large. In the light of the sampling results and the fact that an adult sheep produces roughly $435 \mathrm{~g}$ of dung per day (I. Hervás, personal observation), the mean daily seed input was 133 in 1998 and 657 in 1999. This large variation between the two study years may have been caused by the differing rainfall distribution and volume, and its effects on the vegetation. The 1998 spring was particularly rainy, causing abundant growth of the local herbaceous vegetation. Rainfall and the development of the herbaceous layer were much lower in 1999, probably forcing sheep into a more intense consumption of the Lavandula infructescence. The same diet pattern between woody and herbaceous species has also been detected in other ungulates (Barroso et al., 1997; Hódar et al., 1998). This explanation is supported by the larger number of species and viable seeds from herbaceous species in the analysed dung samples in 1998 than in 1999 (Table 2). In contrast, the 1999 samples yielded a larger number of woody species.

The range of sheep-borne Lavandula endozoochorous dispersal is presumably high and determined by livestock movements. The distance travelled by flocks varies from one area to another, but is always within the order of several kilometres. In addition, this type of livestock was traditionally involved in seasonal transhumance between the north and the south of the Iberian Peninsula, over distances of up to $600-800 \mathrm{~km}$ in daily stages of $20-30 \mathrm{~km}$ (Ruiz and Ruiz, 1986; Vera y Vega, 1986). To some extent this practice still occurs in the form of livestock trucking, which is an indication of the long potential dispersal distances of seeds consumed by sheep.

The fact that Lavandula seeds are dispersed by sheep may explain the type of environments occupied by the species. Sheep can feed in rough, patchy grasslands, and thus flocks graze in thickets, wasteland, fallow fields and crop stubble (Montoya, 1983; Vera y Vega, 1986). Sheep that enter abandoned cropland or graze sporadically on heavily disturbed old pastures may be responsible for the appearance in recent years of numerous Lavandula populations in
- areas where traditional farming practices have been abandoned (Bernáldez, 1991; Tanarro, 1996).

It is also known that sheep are responsible for the epizoochorous dispersal of large numbers of seeds with specialized structures, but also small, flat seeds (Ridley, 1930; Fischer et al., 1996). The dense structure of Lavandula thickets probably leads to a considerable occurrence of epizoochory. This aspect was analysed in experiments by Traba (2000) in the same study area, where Lavandula was found amongst the seeds dispersed by this mechanism. Thus, in order to complete the information on the role of sheep as Lavandula seed dispersers, it is necessary to evaluate the number of seeds dispersed epizoochorally by sheep and the distance they travelled prior to becoming detached.

At present we are unaware of whether Lavandula seeds are dispersed by other herbivores, although viable seeds have been found in rabbit pellets (Sánchez, unpublished data).

\section{Establishment}

The number of seeds that germinated and established in the experimental plots sown with sheep dung samples from the study area was apparently very low. However, considering the total daily weight of dung produced by sheep, the number of seedlings established is potentially extremely high. In addition, the number could be much higher in years such as 1999, when the viable seed density contained in dung was higher. Moreover, the number of estimated seedlings could be underestimated given the apparently low number of Lavandula seeds available in the sown volume of dung. Sowing in spring, when the majority of Lavandula seeds germinate in autumn under natural conditions, may also have affected the results. However, we lack sufficient data to reach a firm conclusion in this respect, given that $40 \%$ of seeds also germinate in winter and spring (Sánchez and Peco, 1999), and the time of year when dungdispersed seeds germinate under natural conditions is not known. All the same, this test should be regarded as an initial experimental approach to the analysis of seedling establishment, and the results could be corroborated by sowing a larger amount of dung per sample in autumn.

Judging by the aspect of the plant remains in September, the high seedling mortality yielded by this experiment was probably largely due to water stress in summer. Similar levels of Lavandula seedling mortality have also been found under natural conditions (Sánchez and Peco, 1999).

Endozoochorous dispersal can affect seed viability through the digestion process and also after defecation, when seeds are returned to the soil amongst the dung. The latter effect was analysed experimentally, yielding 
Barroso, F.G., Alados, C.L. and Boza, J. (1997) Influencia del régimen de precipitaciones sobre la dieta del ganado caprino en zonas áridas. Pastos 39, 515-521.

Bekker, R.M., Bakker, J.P., Grandin, U., Kalamees, R., Milberg, P., Poschlod, P., Thompson, K. and Willems, J.H. (1998) Seed size, shape and vertical distribution in the soil: indicators of seed longevity. Functional Ecology $12,834-842$.

Bernáldez, F.G. (1991) Ecological consequences of the abandonment of traditional land use systems in central Spain. Options Méditerrannéennes - Série Séminaires 15, -23-29.

Bond, W.J., Yeaton, R. and Stock, W.D. (1991) Myrmecochory in Cape fynbos. pp. 449-462 in Husley, C.R.; Cutler, D.F. (Eds) Ant-plant interactions. Oxford, Oxford University Press.

Booth, B.D. and Larson, D.W. (1988) The role of seed rain in determining the assembly of a cliff community. Journal of Vegetation Science 9, 657-668.

Brown, J.R. and Archer, S. (1987) Woody plant seed dispersal and gap formation in a North American subtropical savannah woodland: the role of domestic herbivores. Vegetatio 73, 73-80.

Brown, J.R. and Archer, S. (1989) Woody plant invasion of grassland: establishment of honey mesquite (Prosopis glandulosa var. glandulosa) on sites differing on herbaceous biomass and grazing history. Oecologia 80, 19-26.

Cerván, M. and Pardo, F. (1997) Dispersión de seeds de retama (Retama sphaerocarpa (L.) Boiss.) por el conejo (Oryctogalus cuniculus L.) en el centro de España. Doñana Acta Vertebrata 24 (1-2), 143-154.

Cobo, M. and Andreu, A. (1988) Seed consumption and dispersal by the spur-thighed tortoise. Testugo graeca. Oikos 51, 267-273.

Costa, M. (1974) Estudio fitosociológico de los matorrales de la provincia de Madrid. Analales del Jardín Botánico A.J. Cavanilles 31 (1), 225-315.

Devesa, J.A., Arroyo, J. and Herrera, J. (1985) Contribución al conocimiento de la biología floral del género Lavandula L. Anales del Jardín Botánico de Madrid 42 (1), 165-186.

Díaz-Barradas, M.C., Mateos, M.A., Orellana, R., Zunzunegui, M. and García Novo, F. (1999) Changes in the canopy structure of the Mediterranean shrub Lavandula stoechas after disturbance. Iournal of Vegetation Science 10, 449-456.

Eriksson, O. and Ehrlén, J. (1992) Seed and microsite limitation of recruitment in plant populations. Oecolgia 91, 360-364.

Fischer, S.F., Poschlod, P. and Beinlich, B. (1996) Experimental studies on the dispersal of plants and animals on sheep in calcareous grasslands. Journal of Applied Ecology 33, 1206-1222.

Friedman, J. and Orshan, G. (1975) The distribution, emergence and survival of seedlings of Artemisia herbaalba Asso in the Negev desert of Israel in relation to distance from the adult plants. Journal of Ecology 63, 627-632.

Gardener, C.J., McIvor, J.G. and Jansen, A. (1993a) Passage of legume and grass seeds through the digestive tract of cattle and their survival in faeces. Journal of Applied Ecology 30, 63-74.
Gardener, C.J., McIvor, J.G. and Jansen, A. (1993b) Survival of seeds of tropical grassland species subjected to bovine digestion. Journal of Applied Ecology 30, 75-85.

Gibson, C.W.D., Watt, T.A. and Brown, V.K. (1987) The use of sheep grazing to recreate species-rich grasslands from abandoned arable land. Biological Conservation 42, 165-183.

Guitián, J. and Sánchez, J.M. (1992) Seed dispersal spectra of plant communities on the Iberian Peninsula. Vegetatio $98,157-164$.

Harbone, J. B. (1988) Introduction to ecological biochemistry. London, Academic Press.

Herrera, C.M. (1984a) A study of avian frugivores, birddispersed plants, and their interaction in Mediterranean scrublands. Ecological Monographs 54, 1-23.

Herrera, C.M. (1984b) Tipos morfológicos y funcionales en plantas del matorral mediteráneo del sur de España. Studia Oecologica 5, 7-34.

Herrera, C.M. (1992) Historical effects and sorting processes as explanations for contemporary ecological patterns: character syndromes in Mediterranean woody plants. The American Naturalist 140, 421-446.

Herrera, C.M. (1995) Plant-vertebrate seed dispersal systems in the Mediterranean: ecological, evolutionary, and historical determinants. Annual Review of Ecology and Systematics 26, 705-727.

Herrera, J. (1987) Flower and fruit biology in southern Spanish Mediterranean shrublands. Annals of the Missouri Botanical Garden 74, 69-78.

Herrera, J. (1991) Allocation of reproductive resources within and among inflorescences of Lavandula stoechas (Lamiaceae). American Journal of Botany 78, 789-794.

Herrera, J. (1993) Blooming times of individual inflorescences and plants as determinants of flower and fruit predation in Lavandula stoechas (Lamiaceae). Acta Oecologica 14, 867-874.

Herrera, J. (1997a) The role of colored accessory bracts in the reproductive biology of Lavandula stoechas. Ecology 78, 494-504.

Herrera, J. (1997b) Effects of disturbance on the reproductive potential of Lavandula stoechas, a Mediterranean sclerophyllous shrub. Ecography 20, $88-95$.

Hódar, J.A., Castro, J.M., Gómez, J.M., García, D. and Zamora, R. (1998) Effects of herbivory on growth and survival of seedlings and saplings of Pinus syliestris nevadensis in SE Spain. pp. 264-267 in Papanastasis, V.P.; Peter, D. (Eds) Ecological hasis of livestock grazing in Mediterranean ecosystems. Luxembourg, Official publications of the European Communities.

Howe, H.F. and Smallwood, J. (1982) Ecology of seed dispersal. Annual Review of Ecology and Systematics 13, 201-228.

Janzen, D.H. (1984) Dispersal of small seeds by big herbivores: foliage is the fruit. The American Naturalist 123, 338-353.

Jordano, P. (1995) Angiosperm fleshy fruits and seed dispersers: a comparative analysis of adaptation and constraints in plant-animal interactions. The American Naturalist 145, 163-191.

Karssen, C.M. and Hilhorst, H.W.M. (1992) Effect of chemical environment on seed germination. pp. 327-348 
a positive effect of dung addition on Lavandula seed establishment. This may be due to several factors (Karssen and Hilhorst, 1992), including fertilization, given the oligotrophic nature of the soils in the study area. Furthermore, given that sheep dung is clustered in small units, it seems likely that it hydrates easily after a minimum degree of crushing, forming a favourable environment for germination without impeding seedling rooting in the soil.

There is no direct evidence of the effect of gut transition, although some indications suggest an acceleration of Lavandula seed germination: the proportion of total germinating seedlings that appeared in the first growth year $(98.6 \%)$ was considerably higher than the rates obtained for the same species in seed-bank samples from the study area subjected to similar germination conditions (57.14 and $55.46 \%$ in soil collected in autumn 1997 and 1998 respectively, F.M. Azcárate, unpublished data). Digestion can weaken the seed coat, occasionally leading to an acceleration of the germination process (Ridley, 1930; Russi et al., 1992; Gardener et al., 1993b). Available data point in the same direction, although specific tests are necessary to prove the hypothesis for Lavandula.

Knowledge of the degree to which dung-borne seeds are capable of establishment is fundamental if we are to ascertain the degree of importance of this dispersal mechanism for the population dynamics of the dispersed species, in this case Lavandula stoechas subsp. pedunculata. Malo and Suárez (1998) reported successful establishment of other Mediterranean shrub species in deer dung, which is similar to that of sheep, under similar environments to those of the study area. However, the present research project did not cover in situ germination and establishment, and thus no data are available on the degree to which these seeds can become new adults, although knowledge about whether defecated seeds can be established is in itself valuable information. Given the high seedling mortality rates found in the Lavandula populations and the range of environments frequented by sheep, we may presume that the likelihood of survival by sheep-dispersed seeds is higher. Whatever the case, a more rigorous evaluation of this dispersal mechanism would require an analysis of the probability of these dispersed seeds reaching maturity (Schupp, 1995).

\section{Overall considerations}

Endozoochorous dispersal by herbivores has been described for other shrub species (Cerván and Pardo, 1997; Malo and Suárez, 1998). It is quite predictable that, in a Mediterranean grassland composed primarily of annual species, herbivores consume the most palatable parts of shrubs or their fruits in summer, due to their high energy content. In Mediterranean shrub formations, many species have small, hard-coated seeds, especially seeder species (Herrera C.M., 1984b, 1992; Herrera J., 1987), features which may favour the endozoochorous dispersal of these species (Janzen, 1984; Russi et al., 1992; Gardener et al., 1993a, b).

The high essential oil content of labiates and the negative effect of this feature on the palatability of these species has been described elsewhere (Herrera, C.M. 1984b, 1992; Harbone, 1988). These chemical compounds appear in the leaves and especially in the infructescences (Skoula et al., 1996). Thus, they are probably not consumed because of their palatability, but rather their energy content and the scarcity of more palatable resources (Stiles, 1992). We have seen that sheep only consume the infructescences, which protrude out from the leaf canopy, as in other labiates and cistacea. As grazing does not affect the vegetative parts of the plants, this may be a case of intentional diaspore intake (Van der Pijl, 1982). Shrub infructescence intake by sheep is thus closer to the consumption of fleshy fruit of shrub species by birds than accidental endozoochory, where the herbivores are attracted by the vegetative part of the plant and only consume the intermingled seeds (Janzen, 1984).

In summary, our research highlights the shortdistance scope of autochory as a dispersal mechanism and the importance of sheep in intermediate and longdistance dispersal of seeds of Lavandula stoechas subsp. pedunculata. In addition, new data are presented suggesting that herbivore endozoochory is a dispersal process that helps to explain the colonizing potential of a group of Mediterranean shrub species, for most of which no dispersal mechanisms (apart from autochory) have been described previously.

\section{Acknowledgements}

We are grateful to Catherine Levassor for her help with seedling species identification and Juan E. Malo and Francisco M. Azcárate for their comments during preparation of the manuscript. Financial support was received from the Spanish Commission of Science and Technology (CICYT, Project AMB 990382) and the Spanish Ministry of Education and Culture (F.P.I. scholarships to A.M.S.).

\section{References}

Azcárate, F.M., Arqueros, L. and Peco, B. (1998) Seed selection by harvester ants in Mediterranean grass and scrubland. p. 277 in Farina, A.; Kennedy, J.; Bossú, V. (Eds) VIII International Congress of Ecology, Firenze, Italy. INTECOL. 
in Fenner, M. (Ed.) Seeds - the ecology of regeneration in plant communities. Wallingford, CAB International.

Keeley, J.E. (1991) Seed germination and life history syndromes in the California chaparral. The Botanical Review 57, 81-116.

Kershaw, K.A. (1975) Quantitative and dynamic plant ecology. Ontario, Edward Arnold.

Malo, J.E. and Suárez, F. (1995a) Herbivorous mammals as seed dispersers in a Mediterranean dehesa. Oecologia 104, 246-255.

Malo, J.E. and Suárez, F. (1995b) Establishment of pasture species on cattle dung: the role of endozoochorous seeds. Journal of Vegetation Science 6, 169-174.

Malo, J.E. and Suárez, F. (1996) New insights into pasture diversity: the consequences of seed dispersal in herbivore dung. Biodiversity Research 3, 54-57.

Malo, J.E. and Suárez, F. (1998) The dispersal of a dryfruited shrub by red deer in a Mediterranean ecosystem. Ecography 21, 204-211.

Malo, J.E., Jiménez, B. and Suárez, F. (2000) Herbivore dunging and endozoochorous seed deposition in a Mediterranean dehesa. Journal of Range Management 53, 322-328.

Milewski, A.V. and Bond, W.J. (1982) Convergence of myrmecochory in Mediterranean Australia and South Africa. pp. 89-98 in Buckley, R.C. (Ed.) Ant-plant interactions in Australia. The Hague, Dr W. Junk Publishers.

Montoya, J.M. (1983) Pastoralismo mediterráneo. Monograph ICONA 25. Madrid, Ministerio de Agricultura, Pesca y Alimentacíon.

Montoya, J.M., Meson, M.L. and del Castillo, J.R. (1988) Una dehesa testigo. La dehesa de Moncalvillo. Madrid, ICONA.

Muñoz, A. and Devesa, J.A. (1987) Contribución al conocimiento de la biología floral del género Lavandula L. II Lavandula stoechas L. subsp. stoechas. Anales Del Jardín Botánico 44 (1), 63-78.

Murray, B.R. (1998) Density-dependent germination and the role of seed leachate. Australian Journal of Ecology 23, 411-418.

Nathan, R. and Muller-Landau, H.C. (2000) Spatial patterns of seed dispersal, their determinants and consequences for recruitment. Trends in Ecology and Evolution 15, 278-285.

O'Connor, T.G. and Roux, P.W. (1995) Vegetation changes (1949-71) in a semi-arid, grassy dwarf shrubland in the Karoo, South Africa: influence of rainfall variability and grazing by sheep. Journal of Applied Ecology 32, 612-626.

Pakeman, R.J., Engelen, J. and Attwood, J.P. (1999) Rabbit endozoochory and seedbank build-up in an acidic grassland. Plant Ecology 145, 83-90.

Poschlod, P. and Bonn, S. (1998) Changing dispersal processes in the central European landscape since the last ice age: an explanation for the actual decrease of plant species richness in different habitats? Acta Botanica Neerlandica 47, 27-44.

Poschlod, P., Kiefer, S., Tränke, U., Fischer, S. and Bonn, S. (1998) Plant species richness in calcarous grasslands as affected by dispersability in space and time. Applied Vegetation Science 1, 75-90.

Primack, R.B. and Miao, S.L. (1992) Dispersal can limit local plant distribution. Conservation Biology 6, 513-519.
Rabinowitz, D. and Rapp, J.K. (1979) Dual dispersal modes in hairgrass, Agrostis hiemalis (Walt.) B.S.P. (Gramineae) Bulletin of the Torrey Botanical Club 106, 32-36.

Rice, B. and Westoby, M. (1981) Myrmecochory in sclerophyll vegetation of the West Head, New South Wales. Australian Journal of Ecology 6, 291-298.

Ridley, H.N. (1930) The dispersal of plants throughout the world. Ashford, UK, L. Reeve \& Co.

Rivas-Martínez, S. (1990) Vegetación de la Sierra de Guadarrama. Itinera Geobotanica 4, 4-129.

Ruiz, M. and Ruiz, J.P. (1986) Ecological history of transhumance in Spain. Biological Conservation 37, 73-86.

Russi, L., Cocks, P.S. and Roberts, E.H. (1992) The fate of legume seeds eaten by sheep from a Mediterranean grassland. Journal of Applied Ecology 29, 772-778.

Sánchez, A.M. and Peco, B. (1999) Dynamics and distribution of Lavandula stoechas subsp. pedunculata soil seed banks and seedlings in central Spain. p. 259 in Sgardelis, S.P. Pantis, J.D. (Eds) The European dimension in ecology. VIII European Ecological Congress, Halkidiki, Greece.

Schupp, E.W. (1995) Seed-seedling conflicts, habitat choice, and patterns of plant recruitment. American Journal of Botany 82, 399-409.

Shmida, A. and Ellner, S. (1983) Seed dispersal on pastoral grazers in open Mediterranean chaparral, Israel. Israel Journal of Botany 32, 147-159.

Skoula, M., Abidi, C. and Kokkalou, E. (1996) Essential oil variation of Lavandula stoechas L. ssp. stoechas growing wild in Crete (Greece). Biochemical Systematics and Ecology 24, 255-260.

Stiles, E.W. (1992) Animals as seed dispersers. pp. 87-104 in Fenner, M. (Ed.) Seeds - the ecology of regeneration in plant communities. Wallingford, CAB International.

Tanarro, L.M. (1996) Transformaciones socioeconómicas y dinámica del paisaje rural en la vertiente norte de la sierra de Guarrama. pp. 195-210 in Domínguez, R.M.; López, A.T. (Eds) La conservación del paisaje rural. VIIl Jornadas sobre el paisaje. Segovia, Asociación para el estudio del paisaje.

Thompson, K., Bakker, J.P. and Bekker, R.M. (1987) The soil seed banks of North West Europe: methodology, density and longevity. Cambridge, Cambridge University Press.

Tilman, D. (1997) Community invasibility, recruitment limitation, and grassland biodiversity. Ecology 78, 81-92.

Traba, J. (2000) Uso ganadero y diversidad de pastizales. Relaciones con la disponibilidad y el movimiento de propágulos. MSc Thesis, Universidad Autónoma de Madrid.

Van der Pijl, L. (1982) Principles of dispersal in higher plants. Berlin, Springer-Verlag.

Vera y Vega, A. (1986) Alimentación y pastoreo del ganado orino. Córdoba, Servicio de publicaciones de la Universidad de Córdoba.

Vokou, D. (1992) The allelopathic potential of aromatic shrubs in phryganic (east Mediterranean) ecosystems. pp. 304-320 in Rizvi, S.J.H.; Rizvi, V. (Eds) Allelopathy: Basic and applied aspects. London, Chapman \& Hall.

Vokou, D. and Margaris, N.S. (1986) Autoallelopathy of Thymus capitatus. Oecologia Plantarum 7, 157-163.

Welch, D. (1985) Studies in the grazing of heather moorland in north-east Scotland. IV. Seed dispersal and plant 
establishment in dung. Journal of Applied Ecology 22, 461-472.

Werner, P.A. (1974) A seed trap for determining patterns of seed deposition in terrestrial plants. Canadian Journal of Botany 53, 810-813.

Wilkinson, L. (1986) SYSTAT: the system for statistics. Evanston, Illinois, SYSTAT, Inc.

Willson, M. F. (1992) The ecology of seed dispersal. pp.61-85 in Fenner, M. (Ed.) Seeds - the ecology of
- regenexation in plant communities. Wallingford, $\mathrm{CAB}$ International.

Wolff, A. and Debussche, M. (1999) Ants as seed dispersers in a Mediterranean old-field succession. Oikos 84, 443-452.

Received 25 June 2001

accepted after revision 30 November 2001 (c) CAB International 2002 